\title{
Penggunaan Metode Diskusi Kelompok Untuk Meningkatkan Hasil Belajar dan Aktivitas Siswa Kelas VII B SMPN 4 Blitar pada Materi Thaharah
}

\author{
Siti Rohmawati ${ }^{(1)}$ \\ ${ }^{1}$ SMP Negeri 4 Blitar \\ Email: ${ }^{1}$ sitirohmawati2012@gmail.com \\ DOI: https://doi.org/10.28926/riset_konseptual.v2i2.39
}

\begin{abstract}
ABSTRAK
Berdasarkan pada pembelajaran PAI ,siswa tidak aktif dengan indikator yang hanya lima dari 32 siswa,belum ada interaksi antar siswa .Siswa mengalami kesulitan menguasai materi thaharah(hadas besar dan hadas kecil)dengan nilai rata-rata 65 .Karena itu tanggung jawab guru untuk membuat pembelajaran taharah menjadikan siswa lebih aktif dan hasil ulangan meningkat.Berangkat dari permasalahan diatas guru mengadakan PTK.Penelitian ini bertujuan meningkatkan hasil belajar dan aktifitas siswa pada materi thaharah.Strategi yang digunakan adalah penelitian tindakan kelas dengan menerapkan metode diskusi kelompok dan dilaksanakan selama dua siklus.Tempat penelitian dilakukan di SMP N 4 Kota Blitar dengan objek penelitian siswa kelas VII B,sebanyak 32 siswa terdiri dari 18 siswa perempuan dan 14 laki-laki yang dilaksanakan semester II tahun pelajaran 2017/2018.Teknik pengumpulan data melalui lembar observasi aktifitas belajar siswa pada materi persiapan thaharah oleh observer dari teman sejawat.Penelitian di lakukan pada siklus I dan II.Hasil penelitian ini menunjukkan bahwa penggunaan metode diskusi kelompok dapat meningkatkan hasil belajar dan perubahan aktifitas siswa menjadi lebih meningkat .Yaitu nilai rata -rata kelas dari 64 menjadi 76,dan siswa yang berhasil mencapai KKM dari 57\% menjadi $91 \%$. Sedangkan siswa yang aktif belajar siklus I hanya 8 siswa menjadi 20 siswa pada siklus II dari 32 siswa
\end{abstract}

Kata kunci: diskusi kelompok, hasil belajar, aktivitas, thaharah,

\section{PENDAHULUAN}

Pembelajaran materi persiapan ketentuan bersuci dari hadas kecil dan hadas besar mempunyai peran cukup penting dalam kehidupan sehari -hari siswa,baik di masa sekarang dan dimasa akan datang .Oleh karena itu perlu diadakan upaya dalam meningkatnya mutu hasil pembelajaran materi tersebut pada siswa.Salah satu indikasi meningkatnya mutu hasil pembelajaran adalah meningkatnya prestasi hasil belajar dan keaktifan siswa dalam mempelajari materi ketentuan bersuci dari hadas kecil dan hadas besar.

Berbagai upaya guru yang dilakukan guru untuk meningkatkan hasil pembelajaran adalah melalui perbaikan system pengajaran ,peningkatan kwalitas kemampuan guru ,metode pembelajaran dan lain sebagainya.Banyak hal yang dapat di tempuh untuk mencapai tujuan tersebut ,salah satunya adalah bagaimana cara menciptakan suasana belajar yang dapat merangsang pikiran dan kemampuan ,guru serta membutuhkan keaktifan siswa dalam belajar. Untuk mengatasi masalah -masalah tersebut ,bagaimana upaya guru untuk menciptakan dan lebih berhasil bagi siswa

Dalam proses pembelajaran di kelas,guru memegang peranan dalam proses belajar mengajar ,dalam meningkatkan mutu siswa dan sudah menjadi tugas dan tanggung jawab guru untuk membuat pembelajaran ketentuan bersuci dari hadas kecil dan hadas besar lebih efektif ,menarik serta merangsang dan dapat menumbuhkan keaktifan siswa di kelas.

Pada pembelajaran di kelas VII B SMP N 4 Kota Blitar tentang materi ketentuan bersuci hadas kecil dan hadas besar belum di kuasai siswa ,dengan melihat hasil ulangan hanya 54\% dari jumlah siswa yang telah menguasai KKM dan selebihnya belum berhasil menguasai materi.Padahal untuk materi persiapan bersuci diharapkan 
90\% siswa dapat menguasai materi pembelajaran dan keaktifannya juga meningkat .Ini berarti pemahaman konsep siswa tentang persiapan bersuci atau thaharah tersebut terlalu rendah dan belum berhasil .Dimana berdasarkan temuan awal pada pembelajaran PAI ,siswa belum aktif diukur dengan melihat partisipasi yang bertanya hanya lima orang,dan belum ada interaksi antar siswa tidak aktif dalam mengikuti pembelajaran dan kurang semangat dalam belajar karena siswa belum terlibat secara langsung dalam proses pembelajaran untuk menguasai dan menemukan konsepkonsep materi persiapan bersuci.

Metode pembelajaran sangat berpengaruh pada hasil pembelajaran ,diharapkan dengan menggunakan metode diskusi kelompok dapat meningkatkan hasil belajar dan aktifan siswa terhadap materi persiapan bersuci ,sehingga siswa tumbuh keaktifan belajarnya dan juga merasakan manfaat pembelajaran bagi kehidupan nyata .Hal ini sesuai dengan pendekatan CBSA yaitu pemecahan masalah yang dilakukan dalam metode diskusi kelompok dalam pembelajaran persiapan bersuci tersebut.Penggunaan metode diskusi kelompok akan lebih sesuai ,seperti yang disampaikan Tasker (1992) karena siswa berperan aktif dalam membangun pengetahuan secara dalam ,pentingnya membuat kaitan antara gagasan dalam pengkonstruksian secara bermakna ,dan mengaitkan antara gagasan dengan informasi baru yang diterima sehingga keaktifan dan hasil belajar siswa dapat lebih meningkatkan dari sebelumnya

Dalam pembelajaran di kelas guru menerapkan langkah-langkah Model PembelajaranDiskusi Kelompok seperti yang disampaikan oleh Trianto(2007) sebagai berikut (1) Menyampaikan tujuan dan memotivasi siswa, (2) Menyajikan informasi, (3) Mengorganisasikan siswa, (4) Membimbing kelompok bekerja dan belajar, (5) Evaluasi, (6) Memberikan penghargaan.

\section{METODE}

Penelitian ini merupakan penelitian tindakan kelas, karena penelitiannya dilakukan untuk memecahkan permasalahan pembelajaran yang terjadi di dalam kelas. Penelitian yang dilakukan oleh guru terhadap sebuah kelas melalui refleksi diri,dengan tujuan memperbaiki kinerjanya sebagai guru./pendidik yang professional,untuk meningkatkan hasil belajar dan keaktifan siswa. Menurut Kiranawati (2007) Penelitian Tindakan Kelas merupakan suatu bentuk penelitian yang bersifat reflektif yang di lakukan dengan melakukan tindakan-tindakan tertentu agar dapat memperbaiki atau meningkatkan praktik-praktik pembelajaran di kelas.Dari beberapa pernyataan diatas dapat disimpulkan bahwa Penelitian Tindakan Kelas adalah penelltian tindakan yang dilakukan oleh guru melalaui refleksi untuk memperbaiki dan meningkatkan dalam proses pembelajaran dikelas.

Dalam penelitian tindakan kelas ini,guru menjadi peneliti dan penanggung jawab penuh.Guru dalam hal ini peneliti,terlihat secara penuh dalam perencanaan,tindakan,observasi, (Oleh teman sejawat) dan refleksi pada tiap-tiap siklusnya yang saling terkait dan berkelanjutan .Hal ini merupakan salah satu ciri dari penelitian tindakan kelas(PTK) karena peneliti ingin melakukan tindakan perbaikan pembelajaran yang bertujuan untuk meningkatkan hasil belajar dan keaktifan siswa pada materi thaharah kelas VII B di SMP Negeri 4 Kota Blitar

\section{Waktu,Tempat, dan Objek Penelitian}

Penelitian tindakan kelas ini dilakukan di SMP Negeri 4 Kota Blitar pada siswa VIIB semester genap tahun pelajaran 2017/2018.Jumlah siswa yang menjadi obyek penelitian adalah 32 siswa yang terdiri dari 12 siswa perempuan dan 20 siswa laki-laki. Penelitian di laksanakan pada bulan Januari-Pebruari 2018. a. Siklus pertama di laksanakan hari kamis tanggal 11 Januari 2018 .Siklus kedua dilaksanakan hari kamis 1 Pebruari 2018. 
Vol. 2 No. 2, April 2018;

\section{Teknik Pengumpulan Data}

Pengumpulan data merupakan salah satu usaha untuk memperoleh keterangan atau data yang diharapkan dari penelitian secara lengkap dalam penelitian .Teknik pengumpulan data yang dilakukan peneliti tindakan kelas ini adalah pengamatan,serta hasil akhir dari kegiatan evaluasi pembelajaran.Pengumpulan data dilakukan dengan cara observasi selama pelajaran berlangsusng

Pengumpulan data yang digunakan peneliti diperoleh dari siswa melalui tes tulis dalam evaluasi pembelajaran berupa nilai evaluasi hasil belajar,dan dari guru teman sejawat sebagai observer melalui lembar pengamamatan aktifitas belajar siswa.Yang diperoleh ketika proses pembelajaran pada materi thaharah tersebut berlangsusng.

Jadi kegiatan pengumpulan dan menganalisa data tersebut meliputi:1.Melaksanakan tes berupa evaluasi hasil belajar serta membuat perbandingan sebelumnya dan nilai hasil ulangan pada siklus I dan II. 2. Membandingkan rata -rata tes evaluasi yaitu dari keadaan prasiklus,siklus I, dan siklus II. 3. Membandingkan hasil pengamatan tentang keaktifan siswa dari pra siklus I, dan siklus ke II. 4. Menyimpulkan temuan-temuan hasil observasi, yaitu catatan-catatan di lapangan. 5. Sebagai indikator keberhasilan dalam penelitian ini,adanya peningkatan dalam hasil /nilai evaluasi belajar siswa., dan adanya peningkatan keaktifan siswa dalam belajar.

\section{Rancangan Penelitian}

Perencanaan musyawarah dengan guru teman sejawat,menyusun konsep pembelajaran materi persiapan thaharah, menyususn rencana pelaksanaan pembelajaran , menyiapkan lembar pengamatan keaktifan siswa,menyiapkan kembar evaluasi pembelajaran.

Pelaksanaan siklus I, guru melakukan apersepsi dan memotivasi siswa, guru menyampaikan tujuan pembelajaran persiapan thaharah.Siswa diajak membuat kesepakatan. Siswa dibagi menjadi beberapa kelompok .Siswa diskusi kelompok mengerjakan tugas tentang persiapan thaharah. Siswa menyampaikan hasil kerja kelompok. Guru mengadakan evaluasi pembelajaran.

Pengamatan analisis data. Pengamatan di lakukan ketika siswa sedang melaksanakan kegiatan pembelajaran yaitu diskusi kelompok dan hasil pembelajaran yaitu diskusi kelompok dan hasil pembelajaran.Pengumpulan dan pengamatan data melalui lembar pengamatan aktifitas belajar siswa oleh guru teman sejawat sebagai observer.Data dari lembar evaluasi hasil belajar.

Refleksi dalam tahap refleksi guru mengevaluasi seluruh kegiatan pembelajaran yang telah dilaksanakan dan didasarkan pada hasil pengamatan. Apakah siswa mampu meningkatkan kemampuannya terhadap pelajaran thaharah. Jika dalam pembelajaran pada siklus I belum mencapai kriteria keberhasilan yang ditetapkan, maka dilaksanakan siklus ke II.

Perencanaan,menyususn rencana pelaksanaan pembelajaran (siklus)II, menyiapkan lembar tugas siswa, menyiapkan lembar pengamatan keaktifan siswa.

Pelaksanaan siklus II, guru melakukan apersepsi dan motivasi siswa, guru menyampaikan tujuan pembelajaran, siswa diajak membuat kesepakatan belajar, siswa dibagi menjadi beberapa kelompok, guru menyiapkan alat peraga yang berkaitan materi thaharah, siswa diskusi kelompok mengerjakan lembar tugas, siswa menyampaikan hasil kerja kelompok, guru mengadakan evaluasi pembelajaran.

Pengamatan /analisis data:Pengamatan dilakukan ketika siswa sedang melaksakan kegiatan pembelajaran yaitu diskusi kelompok dan hasil evaluasi belajar. Pengamatan yang dilakuakan oleh guru sebagai peneliti dan guru teman sejawat sebagai observaser yang meliputi : Aktifitas siswa dalam pembelajaran , hasil evaluasi belajar.

Refleksi, Dalam tahap refleksi guru berpikir dan mengevaluasi seluruh kegiatan pembelajaran pada siklus II melalui hasil pengamatan dan hasil evaluasi 
belajar siswa telah mencapai kriteria keberhasilan yang ditetapkan,dan sudah mencapai hasil belajar seperti yang diharapkan yaitu ketuntasan belajar dan keaktifan siswa telah mencapai $90 \%$.

Untuk analisis tingkat keberhasilan atau prosentase ketuntasan belajar siswa selama proses pembelajaran berlangsung pada tiap siklusnya ,dilakukan dengan cara memberikan evaluasi hasil belajar.Analisis ini dihitung dengan menggunakan statistic sederhana.Peneliti menjumlahkan nilai yang diperoleh siswa dibagi dengan jumlah siswa sehingga di peroleh nilai rata-rata .Nilai rata-rata ini dapat dengan menggunakan rumus:

$$
\begin{gathered}
X=\sum X \\
\sum N
\end{gathered}
$$

$X=$ Nilai rata-rata

$\sum X=$ Jumlah semua nilai siswa .

$\sum \mathrm{N}=$ Jumlah siswa

Analisis ini dapat dilakukan pada saat tahapan refleksi dan hasil analisis ini di gunakan sebagai bahan refleksi untuk melakukan perencananan siklus selanjutnya,memperbaiki rancangan pembelajaran dan bila mungkin dapat dijadikan pertimbangan dalam penentuan pembelajaran secara tepat.

Untuk mengetahui adanya peningkatan dalam aktifitas siswa,peneliti membandingkan peritem yang ada di lembar pengamatan aktifitas siswa pada siklus I dan siklus II.Sehingga dapat di ketahui dengan jelas perbedaan di masing-masing proses pembelajaran adanya peningkatan pada keaktifan siswa.Sudah barang tentu peneliti di bantu oleh pengamat /observer yaitu guru sebagai teman sejawat dalam pembelajaran di kelas.

\section{HASIL}

Setelah melalui serangkaian tahapan proses penelitian ,didapatkan seperangkat data yang dapat dianalisis untuk mengetahui tingkat keberhasilan penelitian tindakan kelas(PTKO penggunanan metode diskusi kelompok untuk meningkatkan hasil belajar dan keaktifan siswa pada materi thaharah semester genap kelas VII B yaitu di SMPN 4 Kota Blitar Tahun Pelajaran 2017/2018.

Berdasarkan pada kurikulum satuan pendididkan maka tujuan penelitian tindakan kelas (PTK) penggunanan metode diskusi kelompok adalah untuk meningkatkan hasil belajar dan keaktifan siswa pada materi thaharah kelas VII B semester genap tahun pelajaran 2017/2018 di SMP N 4 Kota Blitar.Hal ini adlah untuk mendapatkan gambaran yang nyata tentang usaha-uahayang dilakukan oleh guru pengajar pada materi thaharah untuk meningkatkan hasil belajar dan keaktifan siswa ,seta tingkat penguasaan pada materi thaharah. Hasilnya menunjukkan peningkatan nilai rata -rata kelas dari 64 menjadi 76dan siswa yang berhasil mencapai KKM dari 57 $\%$ menjadi $91 \%$ pada materi thaharah pada siswa kelas VII B di SMP N 4 Kota Blitar.Jadi siswa telah $90 \%$ mencapai ketuntasan belajar dan tingkat keaktifannya meningkat.Hasil penelitian tersebut seperti di bawah ini dan diuraikan dalam pembahasan:

Tabel 1 Hasil Evaluasi Belajar Siswa Siklus I

\begin{tabular}{|c|l|c|c|}
\hline NO & \multicolumn{1}{|c|}{ NAMA SISWA } & NILAI & KETERANGAN \\
\hline 1 & AKHMAD DENDRA FEBRIANO & 55 & Belum tuntas \\
\hline 2 & ASIEL ARTAHSASTA & 70 & Tuntas \\
\hline 3 & AYU KARTIKA SARI & 60 & Belum tuntas \\
\hline 4 & $\begin{array}{l}\text { DEI FANDRA FASTABIKHUL } \\
\text { PUTRA SULUNG }\end{array}$ & 60 & Belum tuntas \\
\hline
\end{tabular}




\begin{tabular}{|c|c|c|c|}
\hline 5 & $\begin{array}{l}\text { DERANI SHERLY PUTRI } \\
\text { VIOLITA }\end{array}$ & 70 & Tuntas \\
\hline 6 & DIAN ANGGITA SARI & 70 & Tuntas \\
\hline 7 & DIANA FISKA STEFAN PUTRI & 70 & Tuntas \\
\hline 8 & DITO FONTANA RAMA & 80 & Tuntas \\
\hline 9 & ELING YOHANA WIBAWANTI & 70 & Tuntas \\
\hline 10 & ERLIN MAULIA SETYORINI & 70 & Tuntas \\
\hline 11 & $\begin{array}{l}\text { FACHRUL MAULANA } \\
\text { FIRMANSYAH }\end{array}$ & 65 & Tuntas \\
\hline 12 & HEPPY KURNIA PUTRI & 60 & Belum tuntas \\
\hline 13 & ILYASA FADHLURRAHMAN & 50 & Belum tuntas \\
\hline 14 & IVANA SALSABILA FATIKASARI & 45 & Belum tuntas \\
\hline 15 & LADY ELTITA ALLICIA & 45 & Belum tuntas \\
\hline 16 & MISY AYURITMANDANI & 70 & Tuntas \\
\hline 17 & MUHAMMAD FIRMANSYAH & 70 & Tuntas \\
\hline 18 & NABILA AZZAHRA VANS HALIM & 55 & Belum tuntas \\
\hline 19 & NASHWA TABITA ALEXA VEGA & 60 & Belum tuntas \\
\hline 20 & NELSEN BUDI KURNIAWAN & 70 & Tuntas \\
\hline 21 & $\begin{array}{l}\text { NOVALDO RAMADHANI } \\
\text { SAPUTRA }\end{array}$ & 80 & Tuntas \\
\hline 22 & PANDU SYAHPUTRA GAUTAMA & 80 & Tuntas \\
\hline 23 & RADITYA FEBRIANKA BUDIONO & 75 & Tuntas \\
\hline 24 & RICO MARDA SAPUTRA & 75 & Tuntas \\
\hline 25 & RIMA MELATI DEWI & 60 & Belum tuntas \\
\hline 26 & $\begin{array}{l}\text { RYAN DIFA SATRIA } \\
\text { DERMAWAN }\end{array}$ & 55 & Belum tuntas \\
\hline 27 & SALSA PUTRI PRAMADHANI & 50 & Belum tuntas \\
\hline 28 & $\begin{array}{l}\text { SELLA ANGELICA DHEA } \\
\text { AMANDA }\end{array}$ & 60 & Belum tuntas \\
\hline 29 & SULTAN IMADDUDIN & 80 & Tuntas \\
\hline 30 & TRISTAN VALENCIO DIXIE & 70 & Tuntas \\
\hline 31 & $\begin{array}{l}\text { VELLYCIA MARCELLINE } \\
\text { ROSETIANINGRUM }\end{array}$ & 70 & Tuntas \\
\hline 32 & $\begin{array}{l}\text { VELLYCIA MARCELLINE } \\
\text { ROSETIANINGRUM }\end{array}$ & 60 & Belum tuntas \\
\hline \multicolumn{4}{|c|}{ Rata-rata kelas } \\
\hline
\end{tabular}

Nilai rata-rata kelas 2075:33 $=64$.Siswa yang sudah mencapai KKM (Kriteria Ketuntasan Minimal) nilai 65 adalah 18 siswa dari 32 siswa atau 57\%. Siswa yang belum mencapai KKM atau tuntas belajar adalah dari 32 siswa atau $43 \%$

Tabel 2 Hasil Evaluasi Belajar Siswa Siklus II

\begin{tabular}{|c|l|c|c|}
\hline NO & \multicolumn{1}{|c|}{ NAMA SISWA } & NILAI & KETERANGAN \\
\hline 1 & AKHMAD DENDRA FEBRIANO & 60 & Tidak tuntas \\
\hline 2 & ASIEL ARTAHSASTA & 70 & Tuntas \\
\hline 3 & AYU KARTIKA SARI & 75 & Tuntas \\
\hline 4 & $\begin{array}{l}\text { DEI FANDRA FASTABIKHUL } \\
\text { PUTRA SULUNG }\end{array}$ & 70 & Tuntas \\
\hline 5 & $\begin{array}{l}\text { DERANI SHERLY PUTRI } \\
\text { VIOLITA }\end{array}$ & 70 & Tuntas \\
\hline 6 & DIAN ANGGITA SARI & 80 & Tuntas \\
\hline 7 & DIANA FISKA STEFAN PUTRI & 95 & \\
\hline
\end{tabular}




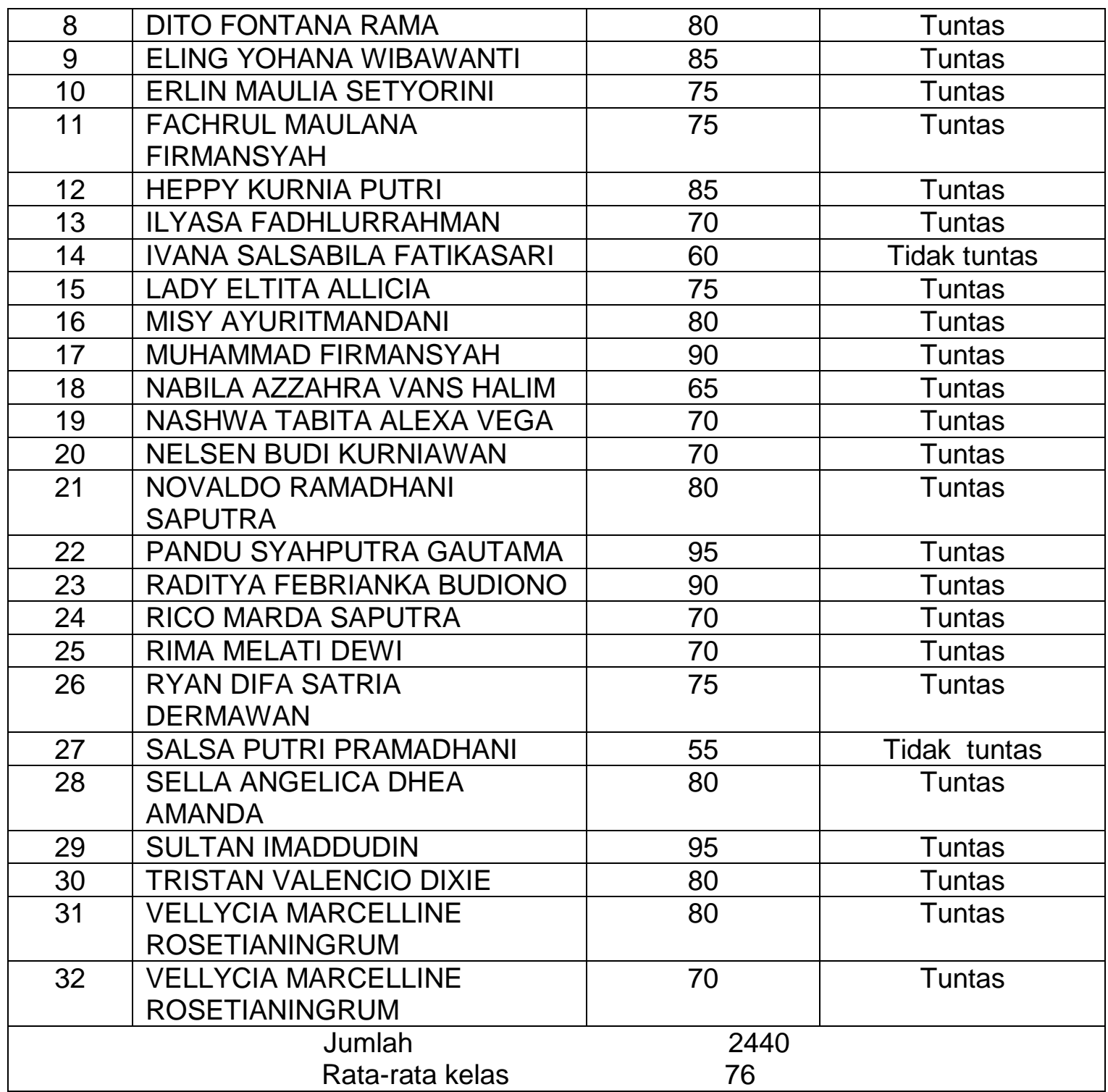

Nilai rata-rata kelas 2440:32 $=76$. Siswa ang sudah mencapai KKM adalah 29 siswa dari 32 siswa atau $91 \%$. Siswa ang belum mencapai KKM adalah 3 siswa dari 32 siswa atau 9\%. Hasil Pengamatan Aktifitsas Belajar Siswa Siklus II .

\section{PEMBAHASAN \\ Siklus I}

Dari pembelajaran sebelumnya didapatkan keadaan siswa tidak aktif ,belum adanya interaksi antar siswa, yang bertanya sedikit, atau tidak mau bertanya dalam mengikuti pelajaran yang dilakukan guru dan hasil evaluasi pembelajaran sangat rendah sekali. Sehingga guru berusaha mengatasi masalah tersebut dengan metode diskusi kelompok. Karena didalam diskusi kelompok siswa akan terlibat aktif dan saling kerjasama menelesaikan tugas, dimana pembelajarannya kelas dibagi dalam beberapa kelompok yang merupakan kesatuan untuk mempelajari materi thaharah tersebut untuk diselesaikan secara bersama-sama.

\section{Siklus II}

Perencanaan : Setelah peniliti selaku pengajar mengadakan refleksi pembelajaran dan perenungan dari siklus pertama berdasarkan hasil lembar pengamatan oleh teman sejawat atau guru lain dan nilai hasil evaluasi belajar siswa, 
Vol. 2 No. 2, April 2018;

dan guru merencanakan pembelajaran kembali yang lebih baik yaitu RPP tentang thaharah.Sehingga akhirnya proses pembelajaran pada siklus kedua guru berusaha menyempurnakan kegiatan pembelajaran dengan berusaha mengaktifkan siswa dan siswa merasa senang dengan belajar dengan menggunakan metode diskusi kelompokdan menambah,memanfaatkan serta memaksimalkan penggunaan lembar tugas metode diskusi kelompok. Dengan tetap mengacu penggunaan metode diskusi kelompok sebagai ssaran penelitian tindakan kelas.

Tabel 3 Data perbandingan hasil belajar dari Pra Siklus,Siklus I, dan Siklus II

\begin{tabular}{|c|c|c|c|c|}
\hline NO & NAMA SISWA & $\begin{array}{c}\text { PRA } \\
\text { SIKLUS }\end{array}$ & NILAI SIKLUS & $\begin{array}{l}\text { NILAI SIKLUS } \\
\text { II }\end{array}$ \\
\hline 1 & $\begin{array}{l}\text { AKHMAD DENDRA } \\
\text { FEBRIANO }\end{array}$ & 50 & 55 & 60 \\
\hline 2 & ASIEL ARTAHSASTA & 70 & 70 & 70 \\
\hline 3 & AYU KARTIKA SARI & 40 & 60 & 75 \\
\hline 4 & $\begin{array}{l}\text { DEI FANDRA FASTABIKHUL } \\
\text { PUTRA SULUNG }\end{array}$ & 60 & 60 & 70 \\
\hline 5 & $\begin{array}{l}\text { DERANI SHERLY PUTRI } \\
\text { VIOLITA }\end{array}$ & 70 & 70 & 70 \\
\hline 6 & DIAN ANGGITA SARI & 70 & 70 & 80 \\
\hline 7 & $\begin{array}{l}\text { DIANA FISKA STEFAN } \\
\text { PUTRI }\end{array}$ & 75 & 70 & 95 \\
\hline 8 & DITO FONTANA RAMA & 55 & 80 & 80 \\
\hline 9 & ELING YOHANA WIBAWANTI & 80 & 70 & 85 \\
\hline 10 & ERLIN MAULIA SETYORINI & 60 & 70 & 75 \\
\hline 11 & $\begin{array}{l}\text { FACHRUL MAULANA } \\
\text { FIRMANSYAH }\end{array}$ & 70 & 65 & 75 \\
\hline 12 & HEPPY KURNIA PUTRI & 50 & 60 & 85 \\
\hline 13 & ILYASA FADHLURRAHMAN & 45 & 50 & 70 \\
\hline 14 & $\begin{array}{l}\text { IVANA SALSABILA } \\
\text { FATIKASARI }\end{array}$ & 45 & 45 & 60 \\
\hline 15 & LADY ELTITA ALLICIA & 55 & 45 & 75 \\
\hline 16 & MISY AYURITMANDANI & 70 & 70 & 80 \\
\hline 17 & MUHAMMAD FIRMANSYAH & 65 & 70 & 90 \\
\hline 18 & $\begin{array}{l}\text { NABILA AZZAHRA VANS } \\
\text { HALIM }\end{array}$ & 45 & 55 & 65 \\
\hline 19 & $\begin{array}{l}\text { NASHWA TABITA ALEXA } \\
\text { VEGA }\end{array}$ & 60 & 60 & 70 \\
\hline 20 & NELSEN BUDI KURNIAWAN & 70 & 70 & 70 \\
\hline 21 & $\begin{array}{l}\text { NOVALDO RAMADHANI } \\
\text { SAPUTRA }\end{array}$ & 75 & 80 & 80 \\
\hline 22 & $\begin{array}{l}\text { PANDU SYAHPUTRA } \\
\text { GAUTAMA }\end{array}$ & 80 & 80 & 95 \\
\hline 23 & $\begin{array}{l}\text { RADITYA FEBRIANKA } \\
\text { BUDIONO }\end{array}$ & 85 & 75 & 90 \\
\hline 24 & RICO MARDA SAPUTRA & 75 & 75 & 70 \\
\hline 25 & RIMA MELATI DEWI & 55 & 60 & 70 \\
\hline 26 & $\begin{array}{l}\text { RYAN DIFA SATRIA } \\
\text { DERMAWAN }\end{array}$ & 40 & 55 & 75 \\
\hline 27 & SALSA PUTRI PRAMADHANI & 45 & 50 & 55 \\
\hline 28 & $\begin{array}{l}\text { SELLA ANGELICA DHEA } \\
\text { AMANDA }\end{array}$ & 70 & 60 & 80 \\
\hline 29 & SULTAN IMADDUDIN & 75 & 80 & 95 \\
\hline
\end{tabular}




\begin{tabular}{|c|l|c|c|c|}
\hline 30 & TRISTAN VALENCIO DIXIE & 70 & 70 & 80 \\
\hline 31 & VELLYCIA MARCELLINE & 65 & 70 & 80 \\
& ROSETIANINGRUM & & & 70 \\
\hline 32 & VELLYCIA MARCELLINE & 50 & 60 & 2440 \\
& ROSETIANINGRUM & 1990 & & 76 \\
\hline
\end{tabular}

Hasil analisa data :Dari proses pembelajaran yang dilaksanakan pada siklus I dan siklus II, pada data diatas menunjukkan ada kenaikkan hasil belajar siswa yaitu:nilai rata-rata kelas dari 64 meningkat menjadi 76 pada siklus II.,-siswa yang berhasil mencapai KKMdari 57\% menjadi 91\% dari jumlah siswa keseluruhan yaitu 32 siswa pada kelas tersebut.

\section{KESIMPULAN}

Dari pelaksanaan perbaikan pembelajaran mata pelajaran pendidikan agama islam pada materi thaharah kelas VII B semester genap dari siklus I dan siklus II dapat di simpulkan sebagai berikut: (1) Penggunaan metode diskusi kelompok dapat meningkatkan hasil belajar pada materi thaharah siswa VII B di SMP N 4 Kota Blitar yaitu nilai rata-rata kelas 64 menjadi 76 dan siswa yang tuntas belajar /berhasil dari 57\% menjadi 91\%. (2) Penggunaan metode diskusi kelompok dapat meningkatkan keaktifan belajar siswa pada materi thaharah siswa kelas VII B,yaitu siswa yang aktif dan sangat aktif dari siklus I ada 8 siswa menjadi 20 siswa pada siklus II dari 32 siswa di kelas tersebut.

\section{SARAN}

Berdasarkan kesimpulan diatas dalam pembelajaran pendidikan agama islam khususnysa materi tentang thaharah sebaiknya menggunakan metode pembelajaran diskusi kelompok karena keaktifan dan pretasi siswa dapat meningkat.

\section{DAFTAR RUJUKAN}

Abimayu Soli. 2008. Strategi Pembelajaran Jakarta : Dirjen Dikti Kiranawati. 2007) . Bagaimana Melaksanakan Penelitian Tindakan Kelas? Nur Muhammad. 2005. Pembelajaran Kooperatif.Pusat Sains dan Matematika Sekolah. Surabaya: UNESA.

Peraturan Menteri Pendidikan Nasional Nomoe 22 tahun 2006 tentang Standart Isi Pendidikan.

Wardani, I.G.A.K. 2006. Penelitian Tindakan Kelas. Jakarta: Universitas Terbuka. 